\title{
Pre-eclampsia and risk of cardiovascular disease and cancer in later life: systematic review and meta-analysis
}

\author{
Leanne Bellamy, medical student, Juan-Pablo Casas, clinical lecturer, ${ }^{2}$ Aroon D Hingorani, reader, ${ }^{3}$ \\ David J Williams, consultant obstetric physician ${ }^{4}$
}

\begin{abstract}
Imperial College School of
Medicine, London

${ }^{2}$ Department of Epidemiology and

Population Health, London School

of Hygiene and Tropical Medicine

${ }^{3}$ British Heart Foundation

Laboratories, Department of

Medicine, University College

London

${ }^{4}$ Institute for Women's Health,

Elizabeth Garrett Anderson

Obstetric Hospital, University

College London, London

WC1E 6DH
\end{abstract}

Correspondence to: D J Williams

d.williams@uclh.nhs.uk

doi:10.1136/bmj.39335.385301.BE

\section{ABSTRACT}

Objective To quantify the risk of future cardiovascular diseases, cancer, and mortality after pre-eclampsia.

Design Systematic review and meta-analysis.

Data sources Embase and Medline without language restrictions, including papers published between 1960 and December 2006, and hand searching of reference lists of relevant articles and reviews for additional reports. Review methods Prospective and retrospective cohort studies were included, providing a dataset of 3488160 women, with 198252 affected by pre-eclampsia

(exposure group) and 29495 episodes of cardiovascular disease and cancer (study outcomes).

Results After pre-eclampsia women have an increased risk of vascular disease. The relative risks ( $95 \%$ confidence intervals) for hypertension were 3.70 (2.70 to 5.05) after 14.1 years weighted mean follow-up, for ischaemic heart disease 2.16 (1.86 to 2.52) after 11.7 years, for stroke 1.81 (1.45 to 2.27) after 10.4 years, and for venous thromboembolism 1.79 (1.37 to 2.33) after 4.7 years. No increase in risk of any cancer was found $(0.96,0.73$ to 1.27$)$, including breast cancer $(1.04,0.78$ to 1.39$) 17$ years after pre-eclampsia. Overall mortality after pre-eclampsia was increased: 1.49 (1.05 to 2.14) after 14.5 years.

Conclusions A history of pre-eclampsia should be considered when evaluating risk of cardiovascular disease in women. This association might reflect a common cause for pre-eclampsia and cardiovascular disease, or an effect of pre-eclampsia on disease development, or both. No association was found between pre-eclampsia and future cancer.

\section{INTRODUCTION}

Pre-eclampsia is a syndrome of pregnancy defined by the onset of hypertension and proteinuria and characterised by widespread dysfunction of the endothelium in the mother. ${ }^{12}$ In the developed world pre-eclampsia affects $3-5 \%$ of first pregnancies. ${ }^{3}$ Worldwide the hypertensive disorders of pregnancy are more common and are responsible for $12 \%$ of maternal mortality during pregnancy and the puerperium. ${ }^{4}$

Changes during healthy pregnancy include insulin resistance ${ }^{5}$ hyperlipidaemia, ${ }^{6}$ hypercoagulability, ${ }^{7}$ inflammation, ${ }^{8}$ and a hyperdynamic circulation ${ }^{9}$. These are exaggerated in women with pre-eclampsia and some are also features of the "metabolic syndrome" a "risk factor" for cardiovascular disease. ${ }^{10}$ It is possible that pre-eclampsia increases risk of later cardiovascular disease, ${ }^{11}$ either because of a shared cause or because subclinical vascular damage occurs during pre-eclampsia.

If a history of pre-eclampsia exerts an independent risk for future cardiovascular disease it may increase the risk of cardiovascular disease in mid-life in affected women, which would render them eligible for preventive therapies at an earlier age than usual. To investigate the association between pre-eclampsia and atherosclerosis in later life we carried out a systematic review and meta-analysis of studies that had estimated the risk of arterial and venous diseases after preeclampsia. We also evaluated the risk of future cancer after pre-eclampsia, in particular breast cancer, one of the commonest causes of death in middle aged women. ${ }^{1314}$ Finally we investigated mortality from any cause after a pregnancy affected by pre-eclampsia.

\section{METHODS}

We searched Medline and Embase with no language restrictions up to December 2006. Additional eligible studies were sought by a hand search of reference lists from primary articles and relevant reviews. (See bmj.com for search terms and combinations).

We included prospective and retrospective cohort studies assessing women of any parity or age or with any severity of pre-eclampsia. To minimise selection or recall bias we excluded case-control studies. We defined a cohort study (including nested case-control and case cohorts) as one that identified pre-eclampsia as the risk factor under investigation and aimed to identify incident disease as the outcome.

Pre-eclampsia was normally defined as the onset of a blood pressure level exceeding 140/90 mm Hg with proteinuria greater than $0.3 \mathrm{~g} / 24 \mathrm{~h}$ after 20 weeks' gestation. ${ }^{2}$ Studies included before 2001 were less exact about the diagnosis of pre-eclampsia, so it is possible that a proportion of cases of pregnancy induced hypertension were misclassified as pre-eclampsia. For this reason we included a separate analysis of studies that had followed up women with isolated pregnancy induced hypertension, defined as the onset of a blood pressure exceeding 


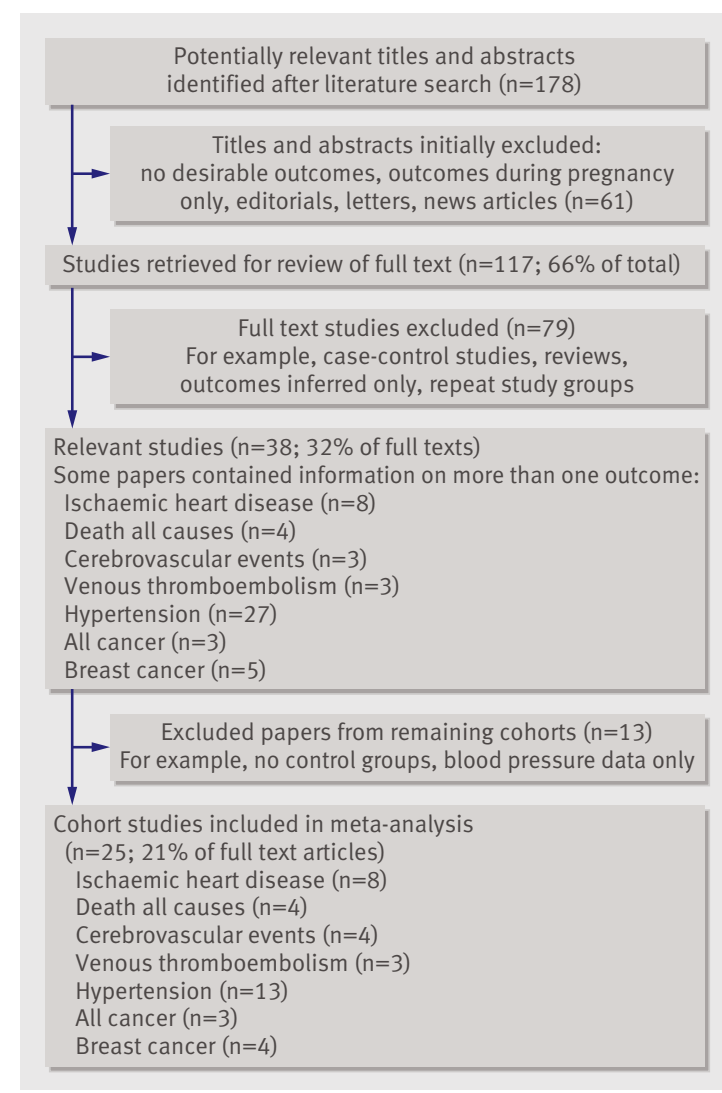

Fig 1 | Study selection process

$140 / 90 \mathrm{~mm} \mathrm{Hg}$ in the absence of proteinuria after 20 weeks' gestation. Severe pre-eclampsia was defined as a blood pressure exceeding 160/110 mm $\mathrm{Hg}$ or proteinuria greater than $5 \mathrm{~g} / 24 \mathrm{~h}$, or both. The comparator group were women who completed pregnancies without developing pre-eclampsia. Outcomes evaluated were hypertension, fatal or non-fatal ischaemic heart disease, stroke, venous thromboembolism, breast cancer, any cancer, and total mortality. Ischaemic heart disease events included myocardial infarction, angina, coronary artery bypass grafting, severe coronary artery ischaemia, and heart failure. Stroke included both haemorrhagic and ischaemic cerebrovascular events. Venous thromboembolism included all deep vein thromboses and pulmonary emboli. Breast cancer was defined as a diagnosis of the cancer or resulting death after the index pregnancy. All outcomes were classified according to the World Health Organization's international classification of disease criteria. As pre-eclampsia resolves within three months of delivery, ${ }^{1516}$ we limited analyses to studies that evaluated outcomes developing after this interval. We excluded studies with historical controls. ${ }^{17}$

Two assessors (LB and JPC) evaluated each included full text article independently and extracted and tabulated all relevant data. Inconsistencies were checked and settled by consensus with all four authors. For additional reports relating to the original cohort, we included the report with the most information relevant to the study question.

We contacted seven authors from six of the included studies w8 w13w15w16w20w22 and received additional unpublished data on numbers of exposed women, incident cases of cardiovascular disease and cancer, and relative risks for studied outcomes.

All procedures and reporting conformed to the meta-analysis of observational studies in epidemiology guidelines. ${ }^{18}$ We excluded 13 unsuitable studies - one with no incident cases in study groups of women who had had pre-eclampsia compared with those who had not had pre-eclampsia, four that reported blood pressure only for both study groups together at follow-up, and eight without control populations.

We utilised the inverse variance weighted method to obtain summary relative risks and 95\% confidence intervals, using random effects models for all analyses. The extent of adjustment for confounding carried out at the level of individual studies was recorded and tabulated. We evaluated small study bias for each outcome by visualisation of funnel plots and an Egger test (by regressing the log relative risk against its standard error; see bmj.com for funnel plot analyses). For each outcome we calculated a weighted mean follow-up in years. We used Revman 4.2.7 and Stata 9.0 for statistical analyses.

Heterogeneity was assessed by $Q$ test and $\mathrm{I}^{2}$ tests. We explored sources of heterogeneity between study groups by evaluating the robustness of the estimate of the effect according to prespecified subgroups by parity, severity of pre-eclampsia, and severity of disease outcome. Instead of generating quality scores for included studies (a controversial approach in synthesis research), we extracted relevant study characteristics for definition of exposure, outcome, sample size (number of incident cases), and degree of confounding, and we used these in a sensitivity analysis.

\section{RESULTS}

Overall 117 full text articles were identified. Thirty eight studies met the inclusion criteria, of which 25 were included. These studies included 29495 incident cases of cardiovascular diseases and cancers among 3488160 women, of whom 198252 had pre-eclampsia and over 3 million did not (comparator group; fig 1).

\section{Pre-eclampsia and risk of future hypertension}

In 13 studies (21 030 women) fulfilling the criteria for risk of future hypertension, 1885 of 3658 women who had pre-eclampsia developed chronic hypertension in later life (table 1). ${ }^{\text {wl-w13 }}$ The mean weighted follow-up was 14.1 years.

The relative risk of a later diagnosis of hypertension in women after pre-eclampsia was 3.70 (95\% confidence interval 2.70 to 5.05 ) compared with women who did not develop pre-eclampsia. Significant heterogeneity was observed $\left(\mathrm{P}=0.001, \mathrm{I}^{2}=62.6 \%\right.$; fig 2$)$, with evidence that small studies reported larger effect sizes 
(Egger test, $\mathrm{P}=0.014)$. In analyses stratified according to the total number of cases, a smaller risk for hypertension $(2.37,2.11$ to 2.66$)$ was obtained after pooling the two large studies, each with more than 200 cases, compared with the risk from pooling 11 small studies, each with fewer than 200 cases $(4.43,3.24$ to 6.05$)$.

Analysis according to parity indicated a higher relative risk of hypertension after pre-eclampsia in any pregnancy (four studies ${ }^{\mathrm{w} 2 \mathrm{w} 5 \mathrm{w} 10 \mathrm{w11}} ; 5.96,3.42$ to 10.38) compared with pre-eclampsia in the first preg-

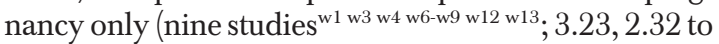
$\left.4.52 ; \chi^{2}=8.48, \mathrm{P}=0.004\right)$.
Pregnancy induced hypertension and risk of future hypertension

Early studies are likely to have misclassified some women with pregnancy induced hypertension as having had pre-eclampsia. Two studies, totalling 2106 women, investigated the association between a history of pregnancy induced hypertension and future hypertension; 454 women had had pregnancy induced hypertension and 300 incident cases of hypertension occurred within 10.8 years. The relative risk of incident hypertension for women who had pregnancy induced hypertension compared with women who did not was

\begin{tabular}{|c|c|c|c|c|c|c|c|c|c|c|c|}
\hline \multirow[b]{2}{*}{ Study, country } & \multirow[b]{2}{*}{$\begin{array}{l}\text { Study } \\
\text { design }\end{array}$} & \multirow[b]{2}{*}{ Exposure } & \multirow[b]{2}{*}{ Race } & \multirow[b]{2}{*}{ Parity } & \multicolumn{2}{|c|}{ Definition of exposure } & \multirow[b]{2}{*}{$\begin{array}{l}\text { No with pre- } \\
\text { eclampsia/No } \\
\text { of women }\end{array}$} & \multirow[b]{2}{*}{$\begin{array}{l}\text { Mean } \\
\text { follow- } \\
\text { up } \\
\text { (years) }\end{array}$} & \multirow[b]{2}{*}{$\begin{array}{c}\text { No with } \\
\text { hypertension }\end{array}$} & \multirow[b]{2}{*}{$\begin{array}{c}\text { Relative risk } \\
(95 \% \mathrm{Cl})\end{array}$} & \multirow[b]{2}{*}{$\begin{array}{c}\text { Extent of } \\
\text { adjustment* }\end{array}$} \\
\hline & & & & & $\begin{array}{l}\text { Minimum } \\
\text { SBP, } \\
\text { minimum } \\
\text { DBP } \\
(\mathrm{mm} \mathrm{Hg})\end{array}$ & $\begin{array}{l}\text { Minimum } \\
\text { proteinuria } \\
\mathrm{g} / 24 \mathrm{~h}\end{array}$ & & & & & \\
\hline $\begin{array}{l}\text { Adams 1961, w1 } \\
\text { UK }\end{array}$ & $\mathrm{RC}$ & Pre-eclampsia & White & $\mathrm{P}$ &,- 90 & 0.25 & 53/334† & 17.6 & $61 \ddagger$ & $\begin{array}{c}5.91 \text { (3.89 to } \\
8.98)\end{array}$ & \\
\hline $\begin{array}{l}\text { Epstein 1964,w2 } \\
\text { USA }\end{array}$ & $\mathrm{RC}$ & Pre-eclampsia & White & Any & $\S, \S$ & $\ddagger$ & $48 / 162 \dagger$ & 15 & 44 & $\begin{array}{c}5.34(2.50 \text { to } \\
11.44)\end{array}$ & \\
\hline $\begin{array}{l}\text { Sibai 1986,"w3 } \\
\text { USA }\end{array}$ & $P C$ & $\begin{array}{l}\text { Pre-eclampsia } \\
\text { and eclampsia }\end{array}$ & Mixed & $P$ & 160,110 & 1 & $406 / 815$ & 7.3 & 83 & $\begin{array}{c}2.63 \text { (1.66 to } \\
4.17)\end{array}$ & \\
\hline $\begin{array}{l}\text { Carleton 1988, w4 } \\
\text { USA }\end{array}$ & $\mathrm{RC}$ & Pre-eclampsia & Mixed & $P$ &,- 85 & 1 & $23 / 46$ & 10.4 & 5 & $\begin{array}{c}1.50(0.28 \text { to } \\
8.16)\end{array}$ & Body mass index \\
\hline $\begin{array}{l}\text { Nisell 1995,w5 } \\
\text { Sweden }\end{array}$ & $\mathrm{RC}$ & Pre-eclampsia & White & Any & 140,90 & 0.3 & $45 / 89$ & 7 & 10 & $\begin{array}{c}8.80(1.16 \text { to } \\
66.59)\end{array}$ & \\
\hline $\begin{array}{l}\text { North 1996, w6 } \\
\text { New Zealand }\end{array}$ & $\mathrm{RC}$ & Pre-eclampsia & $\begin{array}{l}\text { Non- } \\
\text { white } \\
\text { group }\end{array}$ & $P$ & 140,90 & 0.3 & $50 / 100$ & 5 & 21 & $\begin{array}{c}20.00(2.79 \text { to } \\
143.38)\end{array}$ & \\
\hline $\begin{array}{l}\text { Laivuori 1996,w7 } \\
\text { Finland }\end{array}$ & $\mathrm{RC}$ & Pre-eclampsia & White & $P$ & 160,110 & 0.3 & $22 / 44$ & 17 & $2 \pi$ & $\begin{array}{c}5.00(0.25 \text { to } \\
98.52)\end{array}$ & \\
\hline $\begin{array}{l}\text { Hannaford } \\
1997,{ }^{\text {w8 }} \text { UK }\end{array}$ & PC & Pre-eclampsia & Mixed & Any & 140,90 & 0.3 & $2371 / 17202$ & $12.5^{\star \star}$ & $1299+\dagger$ & $\begin{array}{c}2.35(2.08 \text { to } \\
2.65)\end{array}$ & $\begin{array}{l}\text { Smoking, } \\
\text { socioeconomic } \\
\text { status }\end{array}$ \\
\hline $\begin{array}{l}\text { Marin 2000,w9 } \\
\text { Spain }\end{array}$ & $\mathrm{RC}$ and $\mathrm{PC}$ & Pre-eclampsia & White & $P$ & 140,90 & 0.3 & $80 / 166$ & 14.2 & $42 \dagger \dagger$ & $\begin{array}{c}3.70 \text { (1.72 to } \\
7.97)\end{array}$ & $\begin{array}{l}\text { Body mass index } \\
\text { socioeconomic } \\
\text { status, } \\
\text { hypercholestero- } \\
\text { laemia, type } 2 \\
\text { diabetes mellitus }\end{array}$ \\
\hline $\begin{array}{l}\text { Shammas } \\
2000,{ }^{\text {w10 }} \text { Jordan }\end{array}$ & $\mathrm{RC}$ & Pre-eclampsia & Mixed & Any & $\begin{array}{l}\text { Diagnosis } \\
\text { of pre- } \\
\text { eclampsia } \\
\text { in medical } \\
\text { records }\end{array}$ & $\begin{array}{l}\text { Diagnosis of } \\
\text { pre-eclampsia } \\
\text { in medical } \\
\text { records }\end{array}$ & $47 / 93$ & 10 & 26 & $\begin{array}{c}7.50(2.42 \text { to } \\
23.28)\end{array}$ & \\
\hline $\begin{array}{l}\text { Hubel 2000, } \\
\text { Iceland }\end{array}$ & $\mathrm{RC}$ & Eclampsia & White & Any & 140,90 & $\ddagger$ & $30 / 60$ & 32.65 & $12 \ddagger \ddagger$ & $\begin{array}{c}5.00(1.19 \text { to } \\
20.92)\end{array}$ & \\
\hline $\begin{array}{l}\text { Sattar 2003,w12 } \\
\text { Scotland }\end{array}$ & $\mathrm{RC}$ & Pre-eclampsia & White & $P$ & 140,90 & 0.3 & $40 / 80$ & 19 & $9 \ddagger \ddagger$ & $\begin{array}{c}3.50(0.77 \text { to } \\
15.83)\end{array}$ & $\begin{array}{l}\text { Body mass index } \\
\text { smoking }\end{array}$ \\
\hline $\begin{array}{l}\text { Wilson 2003, } \\
\text { Scotland }\end{array}$ & $\mathrm{RC}$ & $\begin{array}{l}\text { Pre-eclampsia } \\
\text { and eclampsia }\end{array}$ & White & $P$ &,- 90 & 0.3 & $443 / 1839$ & 32 & $271 \S \S$ & $\begin{array}{c}2.62(1.77 \text { to } \\
3.86)\end{array}$ & $\begin{array}{l}\text { Socioeconomic } \\
\text { status }\end{array}$ \\
\hline Total & & & & & & & $\begin{array}{c}\text { 3658/21 } \\
\text { 030भा }\end{array}$ & 14.1 & 1885 & & \\
\hline
\end{tabular}

$\mathrm{SBP}=$ systolic blood pressure; $\mathrm{DBP}=$ diastolic blood pressure; $\mathrm{RC}=$ retrospective cohort; $\mathrm{P}=$ primiparous; $\mathrm{PC}=$ prospective cohort. All papers adjusted/matched for maternal age, parity, year of birth, and hospital of delivery.

*Women with pregnancy induced hypertension who had been classified as mild pre-eclampsia were excluded.

†List of variables used in individual studies to adjust for effect of pre-eclampsia on later risk of chronic disease.

†Diagnosis "eclampsia," proteinuria not recorded.

$\S N e w$ onset hypertension, proteinuria, and oedema in third trimester.

TNumber of cases of hypertension in control group.

${ }^{\star *}$ Calculated from total number of woman years.

t†Codes 400-404 from international classification of diseases, ninth revision.

¥†ypertension defined by hypertensive prescribed.

$\S \S$ Codes 401-404 from international classification of diseases, ninth revision.

ๆๆ 21030 women were reviewed, but 19744 were included in meta-analysis. 296 women with pregnancy induced hypertension were excluded. 


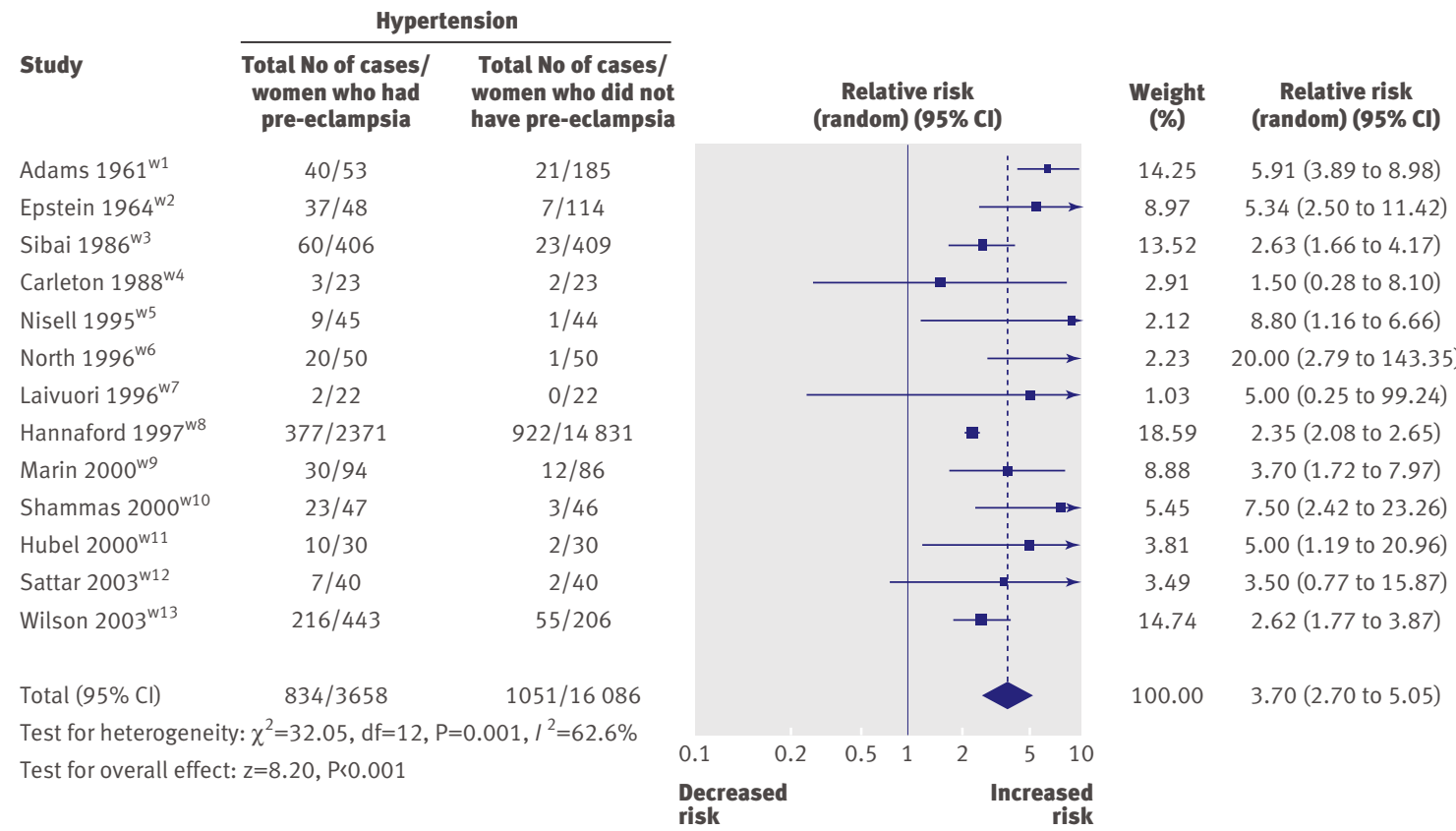

Fig 2 Pre-eclampsia and risk of hypertension in later life

$3.39(0.82$ to $13.92 ; \mathrm{P}$ for heterogeneity $=0.0006$, $\mathrm{I}^{2}=91.4 \%$; see bmj.com). ${ }^{\mathrm{w} 9 \mathrm{w} 13}$ The increase in risk for future cardiovascular disease was 1.66 (0.62 to 4.41 ; $\mathrm{P}$ for heterogeneity $=0.10, \mathrm{I}^{2}=63.8 \%$; see bmj.com). ${ }^{\mathrm{w} 13 \mathrm{w} 14}$

Pre-eclampsia and risk of ischaemic heart disease in later life

Eight studies (2346997 women) contributed to the analysis of fatal and non-fatal ischaemic heart disease (table 2), ${ }^{\text {w w13 w19 }}$ with 121487 women having had preeclampsia and 5097 ischaemic heart disease events. The weighted mean follow-up was 11.7 years. The relative risk of fatal or non-fatal ischaemic heart disease in women with previous pre-eclampsia was over twice that of women who had not developed pre-eclampsia $(2.16,1.86$ to 2.52$)$. No substantial heterogeneity was observed $\left(\mathrm{P}=0.21, \mathrm{I}^{2}=27.1 \%\right.$; figs 3 and 4$)$. The Egger regression test showed no evidence of small study bias $(\mathrm{P}=0.59)$, and no clear asymmetry was observed in the funnel plot.

Six studies assessed primiparous women with preeclampsia $^{\text {w13-w16w18 w19 }}$ and two assessed women with pre-eclampsia in any pregnancy. ${ }^{\text {w8w17 }}$ The risks of ischaemic heart disease were similar in both groups: for primiparous women with pre-eclampsia the risk was 1.89 (1.40 to 2.55$)$ and for women with pre-
Study

\begin{tabular}{|c|c|c|}
\hline Hannaford $1997^{\text {w8 }}$ & $69 / 2371$ & $216 / 14831$ \\
\hline Irgens $2001^{\text {w15 }}$ & $27 / 24155$ & $325 / 602117$ \\
\hline Smith $2001^{\text {w16 }}$ & $12 / 22781$ & $31 / 106509$ \\
\hline Wilson $2003^{\text {w13 }}$ & $26 / 1043$ & $10 / 796$ \\
\hline Kestenbaum $2003^{\text {w14 }}$ & $35 / 20552$ & $64 / 92902$ \\
\hline Funai $2005^{\mathrm{w} 17}$ & $41 / 1070$ & $269 / 35991$ \\
\hline Ray $2005^{\text {w18 }}$ & $228 / 36982^{\ddagger}$ & $1262 / 950885$ \\
\hline Wirkstrom $2005^{\text {w19 }}$ & $176 / 12533$ & $2306 / 383081$ \\
\hline Total $(95 \% \mathrm{Cl})$ & $614 / 121487$ & $4483 / 2187112$ \\
\hline \multicolumn{3}{|c|}{ Test for heterogeneity: $\chi^{2}=9.60, \mathrm{df}=7, \mathrm{P}=0.21, I^{2}=27.1 \%$} \\
\hline for overall effec & $=0.001$ & \\
\hline
\end{tabular}

Fig 3 | Pre-eclampsia and risk of fatal and non-fatal ischaemic heart disease events in later life. *Early and late pre-eclampsia combined (see table 2 ). †Mild and severe pre-eclampsia combined (see table 2 ). $\ddagger$ All maternal placental syndromes 
eclampsia in any pregnancy the risk was 2.23 (1.21 to 4.09; fig 4).

The risk of future fatal ischaemic heart disease events was increased in women after pre-eclampsia. In four studies $^{\text {w13 w15-w17 }}$ a summary relative risk of 2.60 (1.94 to 3.49) was identified for a fatal event. Four other studies included fatal and non-fatal ischaemic heart disease as their outcome after pre-eclampsia ${ }^{\text {w8 }}$ w14 w18 w19 (relative risk 2.17, 1.92 to 2.45 ; fig 4).
In two studies ${ }^{\mathrm{w} 15}$ w16 pre-eclampsia before 37 weeks' gestation was associated with nearly an eightfold increased risk of ischaemic heart disease $(7.71,4.40$ to 13.52) compared with women with normal blood pressure completing pregnancies after 37 weeks' gestation (fig 4).

The severity of pre-eclampsia also increased the risk of later ischaemic heart disease but not to the same extent as the gestation of onset. Two studies ${ }^{\text {w14 }}{ }^{19}$ showed that

\begin{tabular}{|c|c|c|c|c|c|c|c|c|c|c|c|c|}
\hline \multirow[b]{2}{*}{$\begin{array}{l}\text { Study, } \\
\text { country }\end{array}$} & \multirow[b]{2}{*}{$\begin{array}{l}\text { Study } \\
\text { design }\end{array}$} & \multirow[b]{2}{*}{ Condition } & \multirow[b]{2}{*}{ Race } & \multirow[b]{2}{*}{ Parity } & \multicolumn{2}{|c|}{ Definition of exposure } & \multirow[b]{2}{*}{$\begin{array}{l}\text { No with pre- } \\
\text { eclampsia/ } \\
\text { No of women }\end{array}$} & \multirow[b]{2}{*}{$\begin{array}{l}\text { Mean } \\
\text { follow- } \\
\text { up } \\
\text { (years) }\end{array}$} & \multirow[b]{2}{*}{$\begin{array}{l}\text { Primary } \\
\text { outcome }\end{array}$} & \multirow[b]{2}{*}{$\begin{array}{l}\text { No of } \\
\text { cases }\end{array}$} & \multirow[b]{2}{*}{$\begin{array}{c}\text { Relative risk } \\
(95 \% \mathrm{Cl})\end{array}$} & \multirow[b]{2}{*}{$\begin{array}{c}\text { Degree of } \\
\text { adjustment* }\end{array}$} \\
\hline & & & & & $\begin{array}{l}\text { Minimum } \\
\text { SBP, } \\
\text { minimum } \\
\text { DBP (mm } \\
\mathrm{Hg})\end{array}$ & $\begin{array}{l}\text { Minimum } \\
\text { proteinuria } \\
\mathrm{g} / 24 \mathrm{~h}\end{array}$ & & & & & & \\
\hline $\begin{array}{l}\text { Hannaford } \\
1997 \text { UK }^{w 8}\end{array}$ & PC & $\begin{array}{l}\text { Pre- } \\
\text { eclampsia }\end{array}$ & Mixed & Any & 140,90 & 0.3 & 2371/17 202 & $12.5 \dagger$ & Total IHD & 310 & $\begin{array}{c}1.65(1.26 \text { to } \\
2.16)\end{array}$ & $\begin{array}{l}\text { Smoking, } \\
\text { socioeconomic } \\
\text { status }\end{array}$ \\
\hline $\begin{array}{l}\text { Irgens } 2001 \\
\text { Norway }^{\mathrm{w} 1}\end{array}$ & $\mathrm{RC}$ & $\begin{array}{l}\text { Pre- } \\
\text { eclampsia } \\
16-36 \\
\text { weeks; pre- } \\
\text { eclampsia } \geq \\
37 \text { weeks }\end{array}$ & White & $\mathrm{P}$ &,- 85 & - & $\begin{array}{c}2649 ; 21506 / \\
626272\end{array}$ & 13 & IHD death $\ddagger$ & $50 ; 302$ & $\begin{array}{l}8.12(4.31 \text { to } \\
15.33) ; 1.65 \\
(1.01 \text { to } 2.7)\end{array}$ & \\
\hline $\begin{array}{l}\text { Smith } 2001 \\
\text { UK }^{\mathrm{w} 17}\end{array}$ & $\mathrm{RC}$ & $\begin{array}{l}\text { Pre- } \\
\text { eclampsia }\end{array}$ & White & $\mathrm{P}$ & $\S, \S$ & $\S$ & $\begin{array}{c}22781 / 129 \\
290\end{array}$ & 16.9 & IHD deathף & 43 & $\begin{array}{c}1.7 \text { (0.9 to } \\
3.35)\end{array}$ & $\begin{array}{l}\text { Socioeconomic } \\
\text { status }\end{array}$ \\
\hline $\begin{array}{l}\text { Wilson } 2003 \\
\text { UK }^{\text {w14 }}\end{array}$ & $\mathrm{RC}$ & $\begin{array}{l}\text { Pre- } \\
\text { eclampsia } \\
\text { and } \\
\text { eclampsia }\end{array}$ & White & $\mathrm{P}$ &,- 90 & 0.3 & $1043 / 1839$ & 32 & IHD death ${ }^{\star \star}$ & 36 & $\begin{array}{c}1.95 \text { (0.90 to } \\
4.22)\end{array}$ & $\begin{array}{l}\text { Socioeconomic } \\
\text { status }\end{array}$ \\
\hline $\begin{array}{l}\text { Kestenbaum } \\
2003 \text { USA }^{\text {w15 }}\end{array}$ & $\mathrm{RC}$ & $\begin{array}{l}\text { Mild pre- } \\
\text { eclampsia; } \\
\text { severe pre- } \\
\text { eclampsia } \\
\text { and } \\
\text { eclampsia }\end{array}$ & Mixed & $\mathrm{P}$ & $\begin{array}{l}140,90 \\
160,110\end{array}$ & $0.3 ; 0.3$ & $\begin{array}{c}15508 ; 5044 / \\
113454\end{array}$ & 7.8 & IHD event†† & $88 ; 75 \neq \ddagger$ & $\begin{array}{c}2.2(1.3 \text { to } \\
3.6) ; 3.3(1.7 \\
\text { to } 6.5)\end{array}$ & \\
\hline $\begin{array}{l}\text { Funai } 2005 \\
\text { Israel }^{\mathrm{w18}}\end{array}$ & $\mathrm{RC}$ & $\begin{array}{l}\text { Pre- } \\
\text { eclampsia }\end{array}$ & Mixed & Any & 140,90 & $\S \S$ & $1070 / 37061$ & 30 & IHD deathף & 310 & $\begin{array}{c}3.07 \text { (2.18 to } \\
4.33)\end{array}$ & $\begin{array}{l}\text { Socioeconomic } \\
\text { status, type } 2 \\
\text { diabetes mellitus, } \\
\text { gestational diabetes }\end{array}$ \\
\hline $\begin{array}{l}\text { Ray } 2005 \\
\text { Canada }^{\text {w19 }}\end{array}$ & $\mathrm{RC}$ & $\begin{array}{l}\text { Pre- } \\
\text { eclampsia }\end{array}$ & Mixed & $\mathrm{P}$ & 140,90 & 0.3 & $\begin{array}{c}36982 / 1026 \\
265\end{array}$ & 8.7 & IHD eventTी & 1490 & $\begin{array}{c}2.1(1.82 \text { to } \\
2.42)\end{array}$ & $\begin{array}{l}\text { Smoking, } \\
\text { socioeconomic } \\
\text { status, gestational } \\
\text { diabetes, obesity } \\
\text { hypertension, } \\
\text { dyslipidaemia, type } \\
2 \text { diabetes mellitus, } \\
\text { renal disease }\end{array}$ \\
\hline $\begin{array}{l}\text { Wikström } \\
2005 \\
\text { Sweden }^{\text {w20 }}\end{array}$ & $\mathrm{RC}$ & $\begin{array}{l}\text { Mild pre- } \\
\text { eclampsia; } \\
\text { severe pre- } \\
\text { eclampsia } \\
\text { and } \\
\text { eclampsia }\end{array}$ & White & $P$ & $\begin{array}{c}140,90 ;- \\
110\end{array}$ & $0.3 ; 0.5$ & $\begin{array}{c}9718 ; 2815 / \\
395614\end{array}$ & 15 & Total IHDI & $\begin{array}{l}2429 \\
2359\end{array}$ & $\begin{array}{c}1.9(1.6 \text { to } \\
2.2) ; 2.8(2.2 \\
\text { to } 3.7)\end{array}$ & $\begin{array}{l}\text { Socioeconomic } \\
\text { status }\end{array}$ \\
\hline Total & & & & & & & $\begin{array}{l}121487 / 2 \\
346997^{\star \star \star}\end{array}$ & 11.7 & IHD cases & 5097 & & \\
\hline
\end{tabular}

$\mathrm{SBP}=$ systolic blood pressure, $\mathrm{DBP}=$ diastolic blood pressure; $\mathrm{PC}=$ prospective cohort; $\mathrm{IHD}=\mathrm{ischaemic}$ heart disease; $\mathrm{RC}=$ retrospective cohort; $\mathrm{P}=$ primiparous. $\mathrm{All}$ papers adjusted for maternal age, year of birth, and hospital of delivery.

*List of variables used in individual studies to adjust for effect of pre-eclampsia on later risk of chronic disease.

§Hypertension, proteinuria or albuminuria, or both from Scottish morbidity records.

†Calculated from total number of woman years.

¥Codes 410-429 from international classification of diseases, eighth and ninth revisions.

ๆCodes 410-414 from international classification of diseases, ninth revision, and codes 20-25 from 10th revision.

t†Codes 410, 36 (coronary artery bypass graft), 430, 431, 434, 436 from international classification of diseases, ninth revision (stroke included as cardiovascular disease).

$\S \S$ Proteinuria (and oedema) must be present, no minimum value specified.

${ }^{\star *}$ Codes 410-4.428 from international classification of diseases, ninth revision and codes 120-25 and 150 from international classification of diseases, 10 th revision.

TाTCodes 410, 411, 413, 414, and 48 from international classification of diseases, ninth revision and codes I20, I21, I24, I25.0, and I25.1 and respective ICD-10 revisions.

***2346997 women were reviewed, but 2308599 were included in meta-analysis. 38398 non-pre-eclamptic women with maternal placental syndrome were excluded (see Ray $2005^{\text {w19 }}$

$\ddagger \ddagger S a m e$ control group was used for mild and severe pre-eclampsia (99 cases; see fig 3). 
women with severe pre-eclampsia (blood pressure $>160 / 110 \mathrm{~mm} \mathrm{Hg}$ plus proteinuria $>0.3 \mathrm{~g} / 24 \mathrm{~h}^{\mathrm{w} 14}$ or diastolic blood pressure $>110 \mathrm{~mm} \mathrm{Hg}$ plus proteinuria $>5 \mathrm{~g} / 24 \mathrm{~h}^{\text {w20}}$ ) had a greater risk of later ischaemic heart disease $(2.86,2.25$ to 3.65$)$ compared with women with mild pre-eclampsia (1.92, 1.65 to 2.24 ; fig 4$)$.

Pre-eclampsia and risk of stroke in later life

Four studies (1 671578 women) were included involving 64551 women who had pre-eclampsia and 907 incident strokes (table 3). ${ }^{\mathrm{w} 8 \mathrm{w} 13 \mathrm{w} 15 \mathrm{w} 18}$ The mean weighted follow-up was 10.4 years. The overall risk of fatal and non-fatal stroke after pre-eclampsia was 1.81 (1.45 to 2.27) compared with women who did not develop pre-eclampsia. No heterogeneity was observed $\left(\mathrm{P}=0.51 ; \mathrm{I}^{2}=0 \%\right.$; fig 5$)$ and no evidence of small study bias was found (Egger test, $\mathrm{P}=0.82$ ).

Two studies reported on the risk of fatal stroke $\mathrm{w}^{\mathrm{w} 13 \mathrm{w} 15}$ and three examined non-fatal events. ${ }^{\text {w8 }}$ w13 w18 The risk of fatal stroke was greater than the risk of a non-fatal event after pre-eclampsia $(2.98,1.11$ to 7.96 and 1.76 , 1.40 to 2.22 ).

A diagnosis of pre-eclampsia before 37 weeks' gestation $^{\mathrm{w} 15}$ was associated with a higher risk of stroke in later life $(5.08,2.09$ to 12.35$)$ compared with a diagnosis of pre-eclampsia after 37 weeks' gestation $(0.98$, 0.50 to 1.92$) ; \mathrm{P}$ for heterogeneity $\left.0.004 ; \mathrm{I}^{2}=88.1 \%\right) .{ }^{\mathrm{w} 15}$
Pre-eclampsia and risk of venous thromboembolism in later life

Three studies (427693 women) involving 35772 women with pre-eclampsia and 470 incident cases of venous thromboembolism were analysed (table 4). w8 w14 w20 The weighted mean follow-up was 4.7 years. The risk of venous thromboembolism in women who developed pre-eclampsia was 1.79 (1.37 to 2.33 ) compared with women who did not develop pre-eclampsia. No heterogeneity was observed $\left(\mathrm{P}=0.65 ; \mathrm{I}^{2}=0 \%\right.$; fig 5).

In one study severe pre-eclampsia was associated with a higher risk of venous thromboembolism in later life $(2.3,1.3$ to 4.2$)$ compared with mild preeclampsia $(1.4,0.9$ to 2.2$) .{ }^{\text {w14 }}$

\section{Pre-eclampsia and risk of future cancer}

Breast cancer

Four studies (776445 women) including 46593 with pre-eclampsia and 7468 incident events of breast cancer were analysed (table 5). ${ }^{\text {w21-w24 }}$ The average weighted mean follow-up for each woman was 17 years. The relative risk of women who had pre-eclampsia developing breast cancer in later life was 1.04 (0.78 to 1.39). Small study bias was not present (Egger test, $\mathrm{P}=0.37$ ) although important heterogeneity was observed $(\mathrm{P}=0.006$; $\mathrm{I}^{2}=75.7 \%$; fig 6 ). This heterogeneity was not explained by parity. No difference was found in the estimate of the

\begin{tabular}{|c|c|c|c|c|c|c|c|c|c|c|c|c|}
\hline \multirow[b]{2}{*}{$\begin{array}{l}\text { Study, } \\
\text { country }\end{array}$} & \multirow[b]{2}{*}{$\begin{array}{l}\text { Study } \\
\text { design }\end{array}$} & \multirow[b]{2}{*}{ Exposures } & \multirow[b]{2}{*}{ Race } & \multirow[b]{2}{*}{ Parity } & \multicolumn{2}{|c|}{ Definition of exposure } & \multirow[b]{2}{*}{$\begin{array}{l}\text { No with pre- } \\
\text { eclampsia/ } \\
\text { No of } \\
\text { women }\end{array}$} & \multirow[b]{2}{*}{$\begin{array}{l}\text { Mean } \\
\text { follow-up } \\
\text { (years) }\end{array}$} & \multirow[b]{2}{*}{ Primary outcome } & \multirow[b]{2}{*}{$\begin{array}{l}\text { No of } \\
\text { case- } \\
\text { s }\end{array}$} & \multirow[b]{2}{*}{$\begin{array}{l}\text { Relative } \\
\text { risk } \\
(95 \% \mathrm{Cl})\end{array}$} & \multirow[b]{2}{*}{$\begin{array}{c}\text { Degree of } \\
\text { adjustment* }\end{array}$} \\
\hline & & & & & $\begin{array}{l}\text { Minimum } \\
\text { SBP, } \\
\text { minimum } \\
\text { DBP }(\mathrm{mm} \mathrm{Hg})\end{array}$ & $\begin{array}{l}\text { Minimum } \\
\text { proteinuriag/ } \\
24 \mathrm{~h}\end{array}$ & & & & & & \\
\hline $\begin{array}{l}\text { Hannaford } \\
\text { 1997,w8 UK }\end{array}$ & PC & Pre-eclampsia & Mixed & Any & 140,90 & 0.3 & $\begin{array}{c}2371 / 17 \\
202\end{array}$ & $12.5 \dagger$ & $\begin{array}{l}\text { Non-fatal } \\
\text { haemorrhagic or } \\
\text { ischaemic stroke } \neq\end{array}$ & 118 & $\begin{array}{c}1.39 \\
(0.89 \text { to } \\
2.17)\end{array}$ & $\begin{array}{l}\text { Smoking, } \\
\text { socioeconomic } \\
\text { status }\end{array}$ \\
\hline $\begin{array}{l}\text { Irgens } \\
2001 \text {,w16 } \\
\text { Norway }\end{array}$ & $\mathrm{RC}$ & $\begin{array}{l}\text { Pre-eclampsia } \\
\text { 16-36 weeks; } \\
\text { pre-eclampsia } \\
\geq 37 \text { weeks }\end{array}$ & White & $P$ &,- 85 & - & $\begin{array}{c}2649 ; \\
21506 / 626 \\
272\end{array}$ & 13 & Fatal stroke§ & $\begin{array}{l}29 ; \\
277\end{array}$ & $\begin{array}{c}5.08 \\
(2.09 \text { to } \\
12.35) ; \\
0.98(0.5 \\
\text { to } 1.91)\end{array}$ & \\
\hline $\begin{array}{l}\text { Wilson } \\
2003,{ }^{w 14} \text { UK }\end{array}$ & $\mathrm{RC}$ & $\begin{array}{l}\text { Pre-eclampsia } \\
\text { and eclampsia }\end{array}$ & White & $P$ &,- 90 & 0.3 & $1043 / 1839$ & 32 & $\begin{array}{l}\text { Non-fatal } \\
\text { haemorrhagic or } \\
\text { ischaemic } \\
\text { stroke§; fatal } \\
\text { haemorrhagic or } \\
\text { ischaemic stroke§ }\end{array}$ & $47 ; 21$ & $\begin{array}{c}2.1(1.02 \\
\text { to } 4.32) ; \\
3.59 \\
(1.04 \text { to } \\
1.4)\end{array}$ & $\begin{array}{l}\text { Socioeconomic } \\
\text { status }\end{array}$ \\
\hline $\begin{array}{l}\text { Ray 2005, w19 } \\
\text { Canada }\end{array}$ & $\mathrm{RC}$ & Pre-eclampsia & Mixed & $P$ & 140,90 & 0.3 & $\begin{array}{l}36982 / 1 \\
026265\end{array}$ & 8.7 & Non-fatal stroked & 415 & $\begin{array}{l}1.9(1.45 \\
\text { to } 2.27)\end{array}$ & $\begin{array}{l}\text { Smoking, } \\
\text { Socioeconomic } \\
\text { status, } \\
\text { gestational } \\
\text { diabetes, obesity, } \\
\text { dyslipidaemia, } \\
\text { hypertension, } \\
\text { type } 2 \text { diabetes } \\
\text { mellitus, renal } \\
\text { disease }\end{array}$ \\
\hline Total & & & & & & & $\begin{array}{l}64551 / 1 \\
671578^{\star \star}\end{array}$ & 10.4 & All stroke & 907 & & \\
\hline \multicolumn{13}{|c|}{ 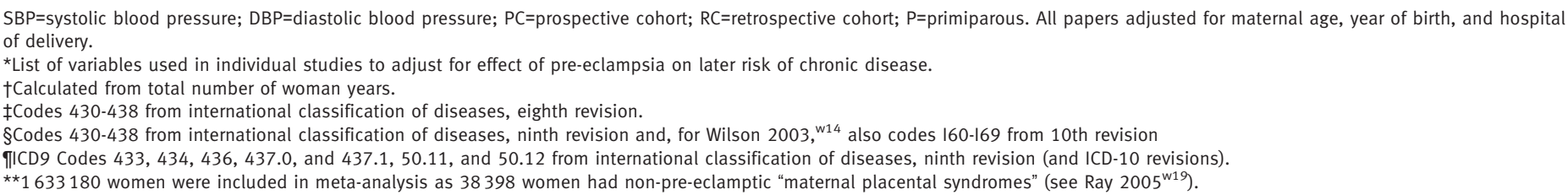 } \\
\hline
\end{tabular}




\section{Group of studies}

Parity

Primiparous: 6 studies ( 4502 cases)

Any pregnancy: 2 studies (595 cases)

\section{Outcome severity}

Fatal ischaemic heart disease: 4 studies (741 cases)

Combined (fatal and non-fatal) ischaemic heart disease: 4 studies ( 4356 cases)

Onset of disease

Early pre-eclampsia: 2 studies (50 cases)*

\section{Severity of pre-eclampsia}

Severe pre-eclampsia: 2 studies (2434 cases)

Mild pre-eclampsia: 2 studies (2517)

Overall relative risk

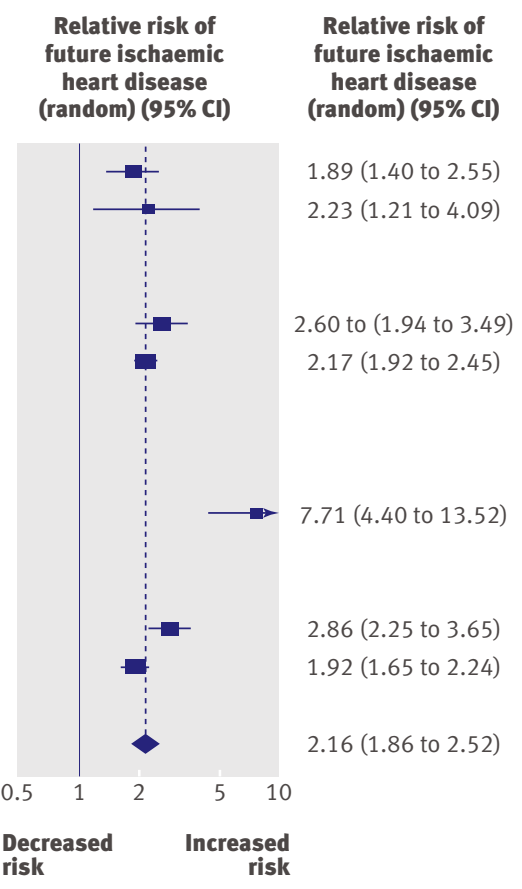

Fig 4 | Pre-eclampsia and risk of ischaemic heart disease in later life by study characteristics. *Only one study included, as data not available from Smith $2001^{\text {w16 }}$

effect between three studies that included women with pre-eclampsia in any pregnancy ${ }^{\text {w21 w22 w24 }}(1.04,0.78$ to 1.39) and one study that assessed only primiparous women $(0.81,0.72$ to 0.92$) .{ }^{\text {w23 }}$

\section{Any cancer}

Three studies (729025 previously pregnant women) were included involving 41084 women with preeclampsia and 6131 incident cancers. ${ }^{\text {w15 w17 w25 }}$ (table 6). The average weighted mean follow-up for each woman was 13.9 years, excluding one study ${ }^{\text {w25 }}$ that presented a range of follow-up rather than a mean number of years. The relative risk of developing any cancer after pre-eclampsia was 0.96 (0.73 to 1.27). No evidence was found of heterogeneity $(\mathrm{P}=0.15$; $\mathrm{I}^{2}=43.2 \%$; fig 6 ) or of small study bias (Egger test, $\mathrm{P}=0.97)$.

Pre-eclampsia and risk of all cause mortality in later life Four studies (794 462 women) included 49049 with pre-eclampsia and 7537 women who later died from all causes $^{\mathrm{w13} \text { w15-w17 }}$ (table 7). The average weighted mean follow-up was 14.5 years for each woman. Women who developed pre-eclampsia had an increased risk of death from any cause compared with women who did not develop pre-eclampsia $(1.49,1.05$ to 2.14$)$. Heterogeneity was substantial $\left(\mathrm{P}<0.00001 ; \mathrm{I}^{2}=93.9 \%\right.$; fig 7) and this was most noticeable between studies of early and late pre-eclampsia $\left(\mathrm{P}<0.00001 ; \mathrm{I}^{2}=96.5 \%\right)$. Women developing pre-eclampsia before 37 weeks' gestation had a relative risk of 2.71 (1.99 to 3.68) of death from any cause in later life compared with women who had normal blood pressure completing pregnancies. ${ }^{\text {w15 }}$ No evidence of small study bias was found (Egger test, $\mathrm{P}=0.84$ ).

\section{DISCUSSION}

A history of pre-eclampsia increases the risk of future hypertension, ischaemic heart disease, stroke, venous thromboembolism, and death from any cause. The major contribution to all cause mortality seems to be cardiovascular disease, as there was no difference in the relative risk of death from breast cancer or any other cancers.

It is possible that much of the excess risk of future ischaemic heart disease and stroke is explained by the link between pre-eclampsia and blood pressure. ${ }^{19}$ Most studies (12 of 15) only made adjustment for age, but three adjusted for diabetes mellitus, features of the metabolic syndrome, smoking, and socioeconomic status. $^{\text {w9 w17 w18 }}$ In one of these studies that included

\begin{tabular}{|c|c|c|c|c|c|c|c|c|c|c|c|}
\hline \multirow[b]{2}{*}{ Study, country } & \multirow[b]{2}{*}{$\begin{array}{l}\text { Study } \\
\text { design }\end{array}$} & \multirow[b]{2}{*}{ Exposures } & \multirow[b]{2}{*}{ Race } & \multirow[b]{2}{*}{ Parity } & \multicolumn{2}{|c|}{ Definition of exposure } & \multirow[b]{2}{*}{$\begin{array}{l}\text { No with pre- } \\
\text { eclampsia/No } \\
\text { of women }\end{array}$} & \multirow[b]{2}{*}{$\begin{array}{l}\text { Mean } \\
\text { follow-up } \\
\text { (years) }\end{array}$} & \multirow[b]{2}{*}{$\begin{array}{c}\text { No of VTE } \\
\text { cases }\end{array}$} & \multirow[b]{2}{*}{$\begin{array}{l}\text { Relative risk } \\
\quad(95 \% \mathrm{Cl})\end{array}$} & \multirow[b]{2}{*}{$\begin{array}{c}\text { Degree of } \\
\text { adjustment* }\end{array}$} \\
\hline & & & & & $\begin{array}{l}\text { Minimum SBP, } \\
\text { minimum DBP } \\
(\mathrm{mm} \mathrm{Hg})\end{array}$ & $\begin{array}{c}\text { Minimum } \\
\text { proteinuria g/ } \\
24 \mathrm{~h}\end{array}$ & & & & & \\
\hline $\begin{array}{l}\text { Hannaford } \\
\text { 1997, w8 UK }\end{array}$ & PC & Pre-eclampsia & 3 & Any & 140,90 & 0.3 & $2371 / 17202$ & $12.5 \dagger$ & $150 \ddagger$ & $\begin{array}{c}1.62(1.09 \text { to } \\
2.41)\end{array}$ & $\begin{array}{l}\text { Smoking, } \\
\text { socioeconomic } \\
\text { status }\end{array}$ \\
\hline $\begin{array}{l}\text { Kestenbaum } \\
2003,{ }^{\text {w14 }} \text { USA }\end{array}$ & $\mathrm{RC}$ & $\begin{array}{l}\text { Mild pre- } \\
\text { eclampsia; } \\
\text { severe pre- } \\
\text { eclampsia and } \\
\text { eclampsia }\end{array}$ & $3 ; 3$ & $\mathrm{P}, \mathrm{P}$ & 140,$90 ; 160,110$ & 0.3 & $\begin{array}{c}15508 ; 5044 / \\
113454\end{array}$ & 7.8 & $\begin{array}{l}141 \S \\
126 \S\end{array}$ & $\begin{array}{l}1.4 \text { (0.9 to } 2.2) \\
2.3 \text { (1.3 to } 4.2)\end{array}$ & \\
\hline $\begin{array}{l}\text { Van Walraven } \\
2003, \text { w20 } \\
\text { Canada }\end{array}$ & PC & Pre-eclampsia & 1 & Any & 140,90 & 0.3 & $12849 / 297037$ & 3 & $164 \S$ & $2.2(1.3$ to 3.7$)$ & \\
\hline Total & & & & & & $:$ & $35772 / 427693$ & 4.7 & 470 & & \\
\hline \multicolumn{12}{|c|}{$\begin{array}{l}\mathrm{SBP}=\text { systolic blood pressure; } \mathrm{DBP}=\text { diastolic blood pressure; } \mathrm{PC}=\text { prospective cohort; } \mathrm{RC}=\text { retrospective cohort; } \mathrm{P}=\text { primiparous. All papers adjusted for maternal age, year of birth, and hospita } \\
\text { of delivery. } \\
\text { *List of variables used in individual studies to adjust for effect of pre-eclampsia on later risk of chronic disease. } \\
\text { †Calculated from total number of woman years. } \\
\begin{array}{l}\ddagger \text { Codes } 450 \text { and } 453 \text { from international classification of diseases, ninth revision. } \\
\text { \$Codes } 415.1 \text { and } 451.1 \text { from international classification of diseases, ninth revision. }\end{array}\end{array}$} \\
\hline
\end{tabular}


Table 5 | Pre-eclampsia and risk of breast cancer in later life

\begin{tabular}{|c|c|c|c|c|c|c|c|c|c|c|c|}
\hline \multirow[b]{2}{*}{$\begin{array}{l}\text { Study, } \\
\text { country }\end{array}$} & \multirow[b]{2}{*}{$\begin{array}{l}\text { Study } \\
\text { design }\end{array}$} & \multirow[b]{2}{*}{ Exposure } & \multirow[b]{2}{*}{ Race } & \multirow[b]{2}{*}{ Parity } & \multicolumn{2}{|c|}{ Definition of exposure } & \multirow[b]{2}{*}{$\begin{array}{l}\text { No with pre- } \\
\text { eclampsia/ } \\
\text { No of women }\end{array}$} & \multirow[b]{2}{*}{$\begin{array}{c}\text { Mean follow- } \\
\text { up (years) }\end{array}$} & \multirow[b]{2}{*}{$\begin{array}{l}\text { No of cancer } \\
\text { cases }\end{array}$} & \multirow[b]{2}{*}{$\begin{array}{c}\text { Relative risk } \\
(95 \% \mathrm{Cl})\end{array}$} & \multirow[b]{2}{*}{$\begin{array}{c}\text { Degree of } \\
\text { adjustment* }\end{array}$} \\
\hline & & & & & $\begin{array}{l}\text { Minimum SBP, } \\
\text { minimum DBP } \\
(\mathrm{mm} \mathrm{Hg})\end{array}$ & $\begin{array}{l}\text { Minimum } \\
\text { proteinur- } \\
\text { ia } \mathrm{g} / 24 \mathrm{~h}\end{array}$ & & & & & \\
\hline $\begin{array}{l}\text { Cohn 2001, w21 } \\
\text { USA }\end{array}$ & PC & Pre-eclampsia & White & Any & 140,90 & $\dagger$ & $88 / 3804$ & 19 & $146 \ddagger$ & $\begin{array}{c}1.16(0.07 \text { to } \\
4.38)\end{array}$ & \\
\hline $\begin{array}{l}\text { Mogren } \\
2001,{ }^{\text {,22 }} \\
\text { Sweden }\end{array}$ & $\mathrm{RC}$ & Pre-eclampsia & White & $P$ & 140,90 & 0.3 & $3397 / 40951$ & 25 & $870 \S$ & $\begin{array}{c}1.09 \text { (0.87 to } \\
1.36)\end{array}$ & \\
\hline $\begin{array}{l}\text { Paltiel } \\
2004,{ }^{24} \\
\text { Israel }\end{array}$ & $\mathrm{RC}$ & Pre-eclampsia & Mixed & Any & 140,90 & $\dagger$ & 1070/37 033 & 30 & $978+\dagger$ & $\begin{array}{c}1.38(1.0 \text { to } \\
1.89)\end{array}$ & $\begin{array}{l}\text { Parity, ethnicity, } \\
\text { religion, type } 1 \\
\text { diabetes mellitus }\end{array}$ \\
\hline Total & & & & & & & $\begin{array}{c}46593 / 776 \\
445\end{array}$ & 17 & 7468 & & \\
\hline
\end{tabular}

$\mathrm{SBP}=$ systolic blood pressure; $\mathrm{DBP}=$ diastolic blood pressure; $\mathrm{PC}=$ prospective cohort; $\mathrm{RC}=$ retrospective cohort; $\mathrm{PIH}=$ pregnancy induced hypertension. All papers adjusted for maternal age, year of birth, and hospital of delivery.

*List of variables used in individual studies to adjust for effect of pre-eclampsia on later risk of chronic disease.

†Proteinuria (and oedema) must be present, no minimum value specified.

$\ddagger$ California cancer registry.

$\S$ Swedish cancer registry.

TPIH and proteinuria as stipulated by Norwegian medical birth registry.

**Norwegian national cancer registry.

t†lsraeli cancer registry.

over a million women the association between preeclampsia and future cardiovascular disease seems to be independent of prepregnancy hypertension, diabetes mellitus, obesity, dyslipidaemia, the metabolic syndrome, and smoking. ${ }^{\text {w18 }}$ We found a similar twofold increased risk of cardiovascular disease in those studies with incomplete adjustment for established cardiovascular risk factors.

Total No of cases/ Total No of cases/ women who had women who did not Relative risk pre-eclampsia have pre-eclampsia (random) $(95 \% \mathrm{Cl})$

Stroke

$25 / 2371$

$14 / 24155$

$50 / 1043$

Irgens $2001^{\text {w15 }}$

$64 / 36982$

$93 / 14831$

292/602 117

$18 / 796$

$351 / 950885$

Ray $2005^{\text {w18 }}$

Total $(95 \% \mathrm{Cl}) \quad 153 / 64551 \quad 754 / 1568629$
Test for heterogeneity: $\chi^{2}=2.33, \mathrm{df}=3, \mathrm{P}=0.51, I^{2}=0 \%$

$754 / 1568629$

Test for overall effect: $z=5.21, P<0.001$

\section{Venous thromboembolism}

Hannaford $1997^{\text {w8 }} \quad 32 / 2371$

Kestenbaum 2003 ${ }^{\text {w14 }}$ 45/20 552

Van Walraven $2003^{\text {w20 }} 15 / 12849$

Total $(95 \% \mathrm{Cl})$

$92 / 35772$

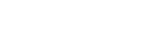

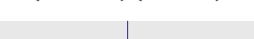

\section{Relative risk (random) $(95 \% \mathrm{Cl})$}

1.39 (0.89 to 2.17 )

$2.17(0.43 \text { to } 10.92)^{\star}$

$2.41(1.29 \text { to } 4.50)^{\dagger}$

1.90 (1.42 to 2.54$)$

1.81 (1.45 to 2.27$)$

1.81 (1.45 to 2.27)

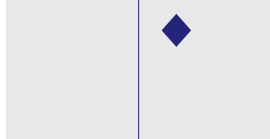

$118 / 14831$

$111 / 92902$

$149 / 284188$

$378 / 391921$

Test for heterogeneity: $\chi^{2}=0.86, \mathrm{df}=2, \mathrm{P}=0.65, \mathrm{I}^{2}=0 \%$

Test for overall effect: $z=4.31, P<0.001$
$0.10 .2 \quad 0.5$

Decreased

risk
Pre-eclampsia most commonly occurs during the first pregnancy. Women who had pre-eclampsia early ( $<37$ weeks' gestation) in their first pregnancy were more likely to have recurrent pre-eclampsia compared with those who had pre-eclampsia late in their first pregnancy ( $>37$ weeks' gestation). Recurrent preeclampsia compared with a single episode has been associated with a sevenfold increased risk of later hypertension. ${ }^{\text {w3 }}$ We also found that pre-eclampsia in any pregnancy compared with pre-eclampsia in only the first pregnancy was associated with a greater relative risk of future hypertension. It is likely that women who have recurrent pre-eclampsia have an underlying pathological phenotype that puts them at risk of hypertension and cardiovascular disease.

We also observed in the sensitivity analysis that women who had early pre-eclampsia had the greatest risk of future cardiovascular disease and this was higher than those who had "severe" pre-eclampsia. This observation was supported by tests of heterogeneity. It follows that the timing of onset of pre-eclampsia more accurately reflects the severity of the maternal cardiovascular phenotype than the severity to which pre-eclampsia may evolve, which more probably reflects the timeliness of antenatal observations.

Most women in the studies in our review will not have reached the menopause by the time of followup, so their absolute risk of ischaemic heart disease is likely to have been low. A woman living in the United Kingdom aged 40-49 years and with an average level of risk factors for cardiovascular disease has an almost $4 \%$ risk of a cardiovascular event within 10 years (J Moon, personal communication, 2007). If the increased risk of cardiovascular disease after pre-eclampsia is independent of these risk factors this risk would increase to around $8 \%$ for an otherwise similar woman with a
Fig 5 | Pre-eclampsia and risk of fatal and non-fatal stroke and thromboembolism in later life. *Early and later pre-eclampsia combined. †Fatal and non-fatal stroke combined. ‡Mild and severe pre-eclampsia combined 
Total No of cases/ Total No of cases/ women who had women who did not Relative risk pre-eclampsia have pre-eclampsia (random) $(95 \% \mathrm{Cl})$

\section{Breast cancer}

Cohn $2001^{\text {w21 }}$

Mogren $2001^{\text {w22 }}$

Vatten $2002^{\text {w23 }}$

Paltiel $2004^{\mathrm{w} 24}$

Total $(95 \% \mathrm{Cl})$
$2 / 88$

$90 / 3397$

$280 / 42038$

$40 / 1070$

$144 / 3716$

$780 / 37554$

$5194 / 652619$

$938 / 35963$

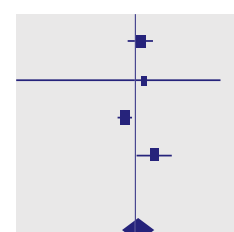

Test for heterogeneity: $\chi^{2}=12.34, \mathrm{df}=3, \mathrm{P}=0.006, \mathrm{I}^{2}=75.5 \%$

Test for overall effect: $z=0.26, P=0.80$

\section{Any cancer}

Irgens 2001 1 15

Funai $2005^{\text {w17 }}$

$65 / 24155$

$27 / 1055$

Aagaard-Tillery $2006^{\text {w25 }} 760 / 15859$

$2031 / 602117$ $631 / 136858$

$2617 / 49833$

$5279 / 688808$

Total $(95 \% \mathrm{Cl})$

$852 / 41069$

Test for heterogeneity: $\chi^{2}=3.73, \mathrm{df}=2, \mathrm{P}=0.16, I^{2}=46.3 \%$

Test for overall effect: $z=0.29, P=0.77$
Relative risk (random) $(95 \% \mathrm{Cl})$

$1.09(0.87$ to 1.36$)$ $1.16(0.07$ to 4.38$)$ 0.81 ( 0.72 to 0.92$)$ 1.38 (1.00 to 1.90$)$ $1.04(0.78$ to 1.39$)$
$0.56(0.23 \text { to } 1.37)^{*}$ $1.26(0.85$ to 1.86$)$ 0.91 (0.84 to 0.99$)$

$0.96(0.73$ to 1.27$)$ $\begin{array}{lllllll}0.1 & 0.2 & 0.5 & 1 & 2 & 5 & 10\end{array}$ $\begin{array}{lr}\begin{array}{l}\text { Decreased } \\ \text { risk }\end{array} & \begin{array}{r}\text { Increased } \\ \text { risk }\end{array}\end{array}$
Fig 6 | Pre-eclampsia and risk of breast cancer or any cancer in later life. *Early and late preeclampsia combined

history of pre-eclampsia. Two reports included in our review followed up women for more than 20 years after pre-eclampsia and the data indicated that the twofold risk of later cardiovascular disease persists long term. $^{\text {w13 } 117}$ Since the risk of a cardiovascular event increases with age, absolute risk at age 50-59 years would be $8.3 \%$ and $17.8 \%$ for a woman without and with a history of pre-eclampsia and at 60-69 years would be $14.2 \%$ and $30.7 \%$, suggesting that a woman with pre-eclampsia might become eligible for primary prevention at an earlier age. ${ }^{20}$ The matter of the independence of the effect of pre-eclampsia on cardiovascular risk could be dealt with by an analysis of data at participant level from studies that measured risk factors.

Most populations included in the systematic review were of European origin, such as women from North America, Canada, and western Europe. It is possible that other ethnic groups will have different risk ratios for future cardiovascular disease. Women of Afro-Caribbean origin have an increased risk of preeclampsia, ${ }^{21}$ which may translate into a higher risk of future cardiovascular disease.

The null association with cancer, a common cause of morbidity and mortality in later life, suggests the associations are specific to cardiovascular disease. This observation may indicate a common cause for preeclampsia and cardiovascular disease or a deleterious effect of pre-eclampsia on the maternal vascular system, or both.

It is possible that transient but severe endothelial dysfunction, observed in pre-eclampsia, ${ }^{1}$ potentiates a cascade of events that progresses to atherosclerosis. Endothelial dysfunction has been observed as early as 23 weeks' gestation in women who develop preeclampsia later, during pre-eclampsia itself, and at least three months after pre-eclampsia has resolved. $^{1-23}$

In support of a common causal link, obesity, hyperlipidaemia, hypertension, and other disorders associated with pre-existing endothelial dysfunction, such as diabetes mellitus and polycystic ovarian syndrome, are risk factors shared by women at risk of both preeclampsia and cardiovascular disease. ${ }^{12}$ Moreover, women with inherited thrombophilias are at increased risk of pre-eclampsia and venous thromboembolic disease. $^{2425}$ A potential role for angiogenic peptides and their endogenous inhibitors in the physiology of pre-eclampsia is in keeping with this hypothesis as these pathways have been implicated in the development of cardiovascular disease. ${ }^{26}$ It is possible

\section{Table 6 | Pre-eclampsia and risk of any cancer in later life}

\begin{tabular}{|c|c|c|c|c|c|c|c|c|c|c|}
\hline \multirow[b]{2}{*}{ Study, country } & \multirow[b]{2}{*}{$\begin{array}{l}\text { Study } \\
\text { de- } \\
\text { sign }\end{array}$} & \multirow[b]{2}{*}{ Exposure } & \multirow[b]{2}{*}{ Race } & \multirow[b]{2}{*}{ Parity } & \multicolumn{2}{|c|}{ Definition of exposure } & \multirow[b]{2}{*}{$\begin{array}{l}\text { No with pre- } \\
\text { eclampsia/ } \\
\text { No of women }\end{array}$} & \multirow[b]{2}{*}{$\begin{array}{l}\text { Mean } \\
\text { follow- } \\
\text { up } \\
\text { (years) }\end{array}$} & \multirow[b]{2}{*}{$\begin{array}{c}\text { Total cases } \\
\text { cancer }\end{array}$} & \multirow[b]{2}{*}{ Relative risk $(95 \% \mathrm{Cl})$} \\
\hline & & & & & $\begin{array}{l}\text { Minimum } \\
\text { SBP, } \\
\text { minimum } \\
\text { DBP (mm } \\
\text { Hg) }\end{array}$ & $\begin{array}{c}\text { Minimum } \\
\text { proteinuria } \mathrm{g} / 24 \mathrm{~h}\end{array}$ & & & & \\
\hline $\begin{array}{l}\text { Irgens 2001, } \\
\text { Norway }\end{array}$ & $\mathrm{RC}$ & $\begin{array}{l}\text { Pre-eclampsia } \\
\text { 16-36 weeks; } \\
\text { pre-eclampsia } \\
\geq 37 \text { weeks }\end{array}$ & White & $\mathrm{P}$ &,- 85 & - & $\begin{array}{c}2649 ; 21506 / \\
626272\end{array}$ & 13 & $123^{*} ; 1973^{*}$ & $\begin{array}{l}0.36(0.12 \text { to } 1.11) \\
0.90(0.29 \text { to } 2.78)\end{array}$ \\
\hline $\begin{array}{l}\text { Funai 2005, w17 } \\
\text { Israel }\end{array}$ & $\mathrm{RC}$ & Pre-eclampsia & Mixed & Any & 140,90 & $\dagger$ & $1070 / 37061$ & 30 & $658 \ddagger$ & $1.26(0.85$ to 1.86$)$ \\
\hline $\begin{array}{l}\text { Aagaard-Tillery } \\
2006,{ }^{\text {w25 }} \text { USA }\end{array}$ & $\mathrm{RC}$ & Pre-eclampsia & Mixed & Any & $\S, \S$ & $\S$ & $\begin{array}{c}15859 / 65 \\
692\end{array}$ & $7-59$ & 33779 & 0.91 (0.84 to 0.99$)$ \\
\hline Total & & & & & & & $\begin{array}{c}41084 / 729 \\
025\end{array}$ & $13.9^{\star \star *}$ & 6131 & \\
\hline
\end{tabular}

$\mathrm{SBP}=$ systolic blood pressure, $\mathrm{DBP}=$ diastolic blood pressure; $\mathrm{RC}=$ retrospective cohort; $\mathrm{P}=$ primiparous. All papers adjusted for maternal age, year of birth, and hospital of delivery

*Codes 140-239 from international classification of diseases, ninth revision and birth record data.

†Proteinuria (and oedema) must be present, no minimum value specified.

†lsraeli cancer registry.

§Codes 6424-6427 from international classification of diseases, ninth revision.

TUtah cancer registry.

${ }^{\star *}$ Overall mean years of follow-up calculated without Aagaard-Tillery data because of presented range only. 


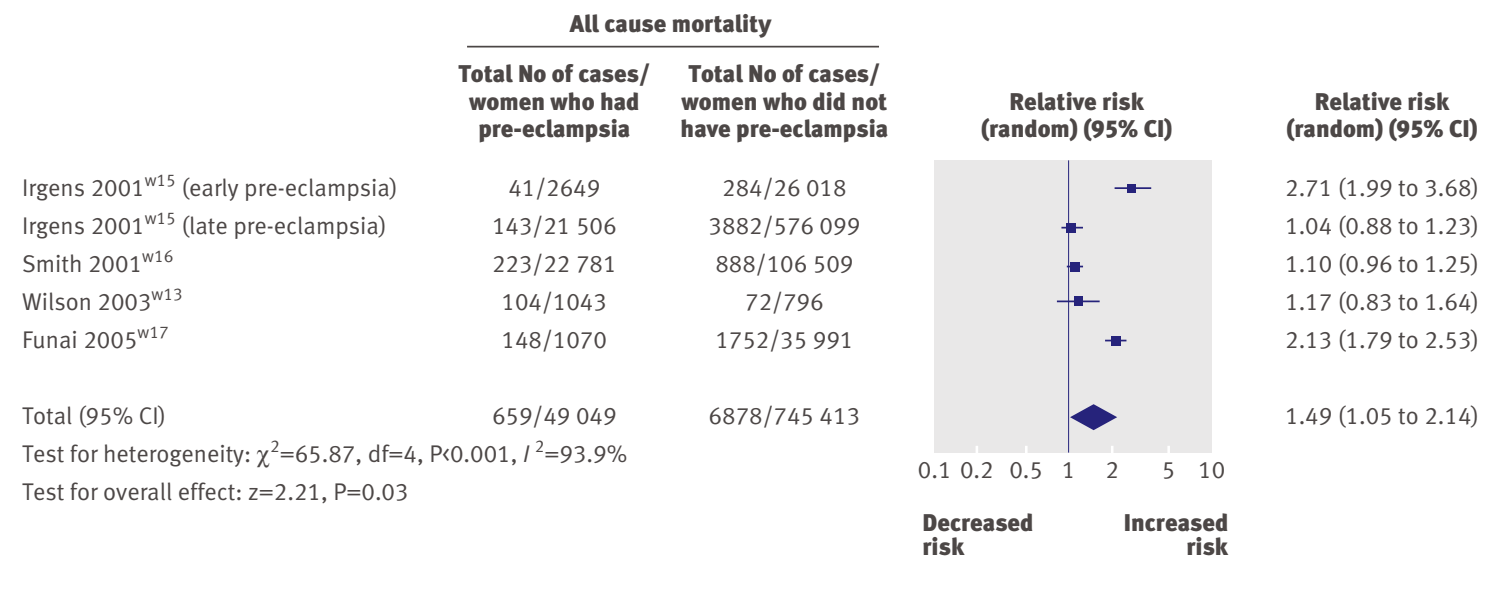

Fig 7| Pre-eclampsia and risk of death from any cause in later life

therefore that pre-eclampsia is the initial point of expression of an inherent adverse phenotype associated with the early development of cardiovascular disease. One exception is the notable discordance between the protective effect of smoking on risk of pre-eclampsia and its deleterious effect on risk of cardiovascular disease. ${ }^{2728}$

It is unlikely that our observations are the result of chance because of the large number of women included ( $>3.4$ million) and the large number of incident cases. Furthermore, there was a strong consistency of the association between pre-eclampsia and future cardiovascular disease in different studies for most end points. The only outcome for which there was evidence of small study bias was incident hypertension (see bmj.com). ${ }^{29}$ Clear concordance was, however, found between the effect estimates of the largest studies included in the meta-analyses and the overall relative risks that we produced for each outcome. The effect estimate for incident hypertension after pre-eclampsia (relative risk 3.7, 2.7 to 5.05) could be an overestimation, and a relative risk less prone to bias would be the one obtained from pooling the largest studies - that is $2.37,2.11$ to 2.66 .

Assessing the quality of included studies is controversial. The application of a quantitative score of study quality as part of study selection in meta-analysis is a process that has not been validated and can itself introduce bias. To overcome this problem we evaluated relevant study characteristics that may introduce bias to the meta-analysis, and we used these characteristics in a sensitivity analysis (fig 4). This approach

\section{Table 7 | Pre-eclampsia and risk of death from any cause in later life}

\begin{tabular}{|c|c|c|c|c|c|c|c|c|c|c|c|}
\hline \multirow[b]{2}{*}{$\begin{array}{l}\text { Study, } \\
\text { country }\end{array}$} & \multirow[b]{2}{*}{$\begin{array}{l}\text { Study } \\
\text { design }\end{array}$} & \multirow[b]{2}{*}{ Exposure } & \multirow[b]{2}{*}{ Race } & \multirow[b]{2}{*}{ Parity } & \multicolumn{2}{|c|}{ Definition of exposure } & \multirow[b]{2}{*}{$\begin{array}{c}\text { No with pre-eclampsia/ } \\
\text { No of women }\end{array}$} & \multirow[b]{2}{*}{$\begin{array}{c}\text { Mean } \\
\text { follow up } \\
\text { (years) }\end{array}$} & \multirow[b]{2}{*}{$\begin{array}{l}\text { No of } \\
\text { cases }\end{array}$} & \multirow[b]{2}{*}{$\begin{array}{l}\text { Relative risk } \\
\qquad(95 \% \mathrm{Cl})\end{array}$} & \multirow[b]{2}{*}{$\begin{array}{l}\text { Degree of } \\
\text { adjustment* }\end{array}$} \\
\hline & & & & & $\begin{array}{c}\text { Minimum SBP, } \\
\text { minimum DBP } \\
(\mathrm{mm} \mathrm{Hg})\end{array}$ & $\begin{array}{l}\text { Minimum } \\
\text { proteinuria } \\
\mathrm{g} / 24 \mathrm{~h}\end{array}$ & & & & & \\
\hline $\begin{array}{l}\text { Irgens } \\
2001 \text {,w15 } \\
\text { Norway }\end{array}$ & $\mathrm{RC}$ & $\begin{array}{l}\text { Pre- } \\
\text { eclampsia } \\
16-36 \text { weeks; } \\
\text { pre- } \\
\text { eclampsia } \geq \\
37 \text { weeks }\end{array}$ & White & $P$ &,- 85 & - & 2649; 21 506/626 272 & 13 & $\begin{array}{l}325 \\
4025\end{array}$ & $\begin{array}{c}2.71(1.99 \text { to } \\
3.68) ; 1.04 \\
(0.88 \text { to } 1.23)\end{array}$ & \\
\hline $\begin{array}{l}\text { Smith } \\
2001, \text { w16 } \\
\text { UK }\end{array}$ & $\mathrm{RC}$ & $\begin{array}{l}\text { Pre- } \\
\text { eclampsia }\end{array}$ & White & $P$ & $\dagger, \dagger$ & $\dagger$ & $22781 / 129290$ & 16.9 & 1111 & $\begin{array}{c}1.1 \text { (0.96 to } \\
1.25)\end{array}$ & $\begin{array}{l}\text { Socioeconomic } \\
\text { status }\end{array}$ \\
\hline $\begin{array}{l}\text { Wilson } \\
2003,{ }^{w 13} \\
\text { UK }\end{array}$ & $\mathrm{RC}$ & $\begin{array}{l}\text { Pre- } \\
\text { eclampsia } \\
\text { and } \\
\text { eclampsia }\end{array}$ & White & $P$ & 90 & 0.3 & $1043 / 1839$ & 32 & 176 & $\begin{array}{c}1.17(0.83 \text { to } \\
1.64)\end{array}$ & $\begin{array}{l}\text { Socioeconomic } \\
\text { status }\end{array}$ \\
\hline $\begin{array}{l}\text { Funai } \\
2005, \text { w17 } \\
\text { Israel }\end{array}$ & $\mathrm{RC}$ & $\begin{array}{l}\text { Pre- } \\
\text { eclampsia }\end{array}$ & Mixed & Any & 140,90 & $\ddagger$ & $1070 / 37061$ & 30 & 1900 & $\begin{array}{c}2.13(1.79 \text { to } \\
2.53)\end{array}$ & $\begin{array}{l}\text { Socioeconomic } \\
\text { status, type } 2 \\
\text { diabetes, } \\
\text { gestational } \\
\text { diabetes }\end{array}$ \\
\hline Total & & & & & & & 49 049/794 462 & 14.5 & 7537 & & \\
\hline
\end{tabular}

$\mathrm{SBP}=$ systolic blood pressure; $\mathrm{DBP}=$ diastolic blood pressure; $\mathrm{RC}=$ retrospective cohort; $\mathrm{P}=$ primiparous. All papers adjusted for maternal age, year of birth, and hospital of delivery.

* List of variables used in individual studies to adjust for effect of pre-eclampsia on later risk of chronic disease.

†Hypertension, proteinuria or albuminuria, or both from Scottish morbidity records.

$\ddagger$ Proteinuria (and oedema) must be present, no minimum value specified. 


\section{WHAT IS ALREADY KNOWN ON THIS TOPIC}

A positive association has been found between pre-eclampsia and future cardiovascular disease but individual studies have had too few incident events to estimate the risks with precision

It is uncertain whether the association is specific to cardiovascular diseases or extends to other common life threatening disorders such as cancer

\section{WHAT THIS STUDY ADDS}

After pre-eclampsia, women have an increased risk of hypertension, fatal and non-fatal ischaemic heart disease, stroke, and venous thromboembolism in later life

Early onset pre-eclampsia ( 337 weeks' gestation) is associated with an even greater risk of future cardiovascular disease

No association was found between pre-eclampsia and future breast cancer

indicated that the findings were robust. Most of the studied cohorts were retrospective, which limited our ability to assess adequately the effect of potential confounders on observed associations.

Some women in older studies with pregnancy induced hypertension may have been misclassified as having pre-eclampsia, but when analyses were restricted to women with a clear phenotype such as severe pre-eclampsia, similar results were obtained. Furthermore, we showed that women who had pregnancy induced hypertension have a similar, but lower, risk of future hypertension and cardiovascular disease as those who had rigorously defined pre-eclampsia (see bmj.com).

The WHO criteria for international classification of diseases were universally adopted for the diagnoses of all outcomes except hypertension. A minimum diastolic blood pressure of $90 \mathrm{~mm} \mathrm{Hg}$ or the use of antihypertensives after the pregnancy with pre-eclampsia were used to diagnose hypertension. As included studies spanned more than 40 years, alterations in diagnostic criteria occurred, with reclassification (eighth, ninth, and 10th revisions). This may not have affected the numbers of future events but may have increased the likelihood of misclassification. Since the overall relative risks were consistently increased for all cardiovascular outcomes, this possibility is unlikely.

\section{Conclusions}

Women who have had pre-eclampsia have an increased risk of cardiovascular disease, including an almost fourfold increased risk of hypertension and an approximately twofold increased risk of fatal and nonfatal ischaemic heart disease, stroke, and venous thromboembolism in later life. This may explain the small increase in risk of death. The lack of association between pre-eclampsia and future cancer, in particular breast cancer, suggests a specific relation between preeclampsia and cardiovascular disease.

The mechanism underlying this association remains to be defined, but whatever its nature a history of preeclampsia should be considered in the evaluation of women's risk of cardiovascular disease. If the risk proves independent of established risk factors for cardiovascular disease, affected women would be eligible for preventive therapies at an earlier age than usual.

We thank the following authors for additional information: Phil Hannaford, Lorentz Irgens, Rolv Lie, Gordon Smith, Brenda Wilson, Carl Van Walraven, and Ingrid Mogren.

Contributors: LB and DJW contributed to conception and design, analysis and interpretation of data, drafting the article and revising and were involved in the final approval of the version to be published. JPC contributed to the analysis and interpretation of data and revising of the article. ADH contributed to

interpretation of the data, drafting and revising of the article and approval of the final paper. ADH has a senior fellowship funded by the British Heart Foundation. DJW had full access to all of the data in the study and takes responsibility for the integrity of the data and the accuracy of the data analysis.

Funding: A proportion of funding was received by UCLH/UCL from the Department of Health's National Institute for Health Research Biomedical Research Centre. ADH is a recipient of a senior research fellowship from the British Heart Foundation

Competing interests: None declared.

Ethical approval: Not required.

1 Roberts IM, Taylor RN, Musci TJ, Rodgers GM, Hubel CA, McLaughlin MK. Preeclampsia: an endothelial cell disorder. Am J Obstet Gynecol 1989;161:1200-4.

2 Brown MA, Lindheimer MD, de Swiet M, Van Assche A, Moutquin JM. The classification and diagnosis of the hypertensive disorders of pregnancy: statement from the International Society for the Study of Hypertension in Pregnancy (ISSHP). Hypertens Pregnancy 2001;20: IX-XIV.

3 World Health Organization Collaboration. Postpartum care of the mother and newborn: a practical guide 1998. Department of Reproductive Health and Research, WHO. www.who.int/ reproductivehealth/publications/msm_98_3/msm_98_3_2.html (accessed Feb 2006).

4 World Health Organization Collaboration. The world health report: make every mother and child count. 2005. Department of Reproductive Health and Research, WHO. www.who.int/whr/2005/ en/index.html (accessed Aug 2006).

5 Seely EW, Solomon CG. Insulin resistance and its potential role in pregnancy-induced hypertension. / Clin Endocrinol Metab 2003;88:2393-8.

6 Ray JG, Diamond P, Singh G, Bell CM. Brief overview of maternal triglycerides as a risk factor for pre-eclampsia. Br J Obstet Gynaecol 2006;113:379-86.

7 Greer IA. Thrombosis in pregnancy: maternal and fetal issues. Lancet 1999;10:1258-65

8 Redman CW, Sacks GP, Sargent IL. Preeclampsia: an excessive maternal inflammatory response to pregnancy. Am J Obstet Gynecol 1999;180:499-506.

9 Bosio PM, Mckenna PJ, Conroy R, O'Herlihy C. Maternal central haemodynamics in hypertensive disorders of pregnancy. Obstet Gynecol 1999;94:978-84.

10 Rodie VA, Freeman DJ, Sattar N, Greer I. Pre-eclampsia and cardiovascular disease: metabolic syndrome of pregnancy? Atherosclerosis 2004;175:189-202.

11 Williams D. Pregnancy: a stress test for life. Curr Opin Obstet Gynaecol 2003;15:1-7.

12 Milne F, Redman C, Walker J, Baker P, Bradley J, Cooper C, et al. The pre-eclampsia community guideline (PRECOG): how to screen for and detect onset of pre-eclampsia in the community. BMJ 2005;330:576-80

13 World Health Organization cancer control programme. www.who.int/ cancer/en/index.html (accessed Sept 2006).

14 World Health Organization. Screening and early detection of cancer: screening for breast cancer. www.who.int/cancer/detection/ breastcancer/en/index.html (accessed Sept 2006).

15 Makkonen N, Harju M, Kirkinen P. Post-partum recovery after severe pre-eclampsia and HELLP syndrome. J Perinatol Med 1996;24:641-9.

16 Ruschtzka F, Schulz E, Kling H, Schrader J, Rath W. Longitudinal study of 24-hour blood pressure behaviour in pregnancy and the puerperium in patients with normal pregnancy, pre-eclampsia and HELLP syndrome. Z Geburtshilfe Neonatol 1996;200:100-3.

17 Chesley LC, Annitto JE, Cosgrove RA. The remote prognosis of eclamptic women, sixth periodic report. Am I Obstet Gynecol 1976;124:446-59.

18 Stroup DF, Berlin JA, Morton SC, Olkin I, Williamson GD, Rennie D, et al. Meta-analysis of observational studies in epidemiology, a proposal for reporting. JAMA 2000;283:2008-12. 
19 Singh MM, Macgillivray I, Mahaffy RG. A study of the long term effects of preeclampsia on blood pressure and renal function. J Obstet Gynaecol 1974;81:903-6.

20 National Institute of Health and Clinical Excellence. Statins for the prevention of cardiovascular events. Technology appraisal 94. London: NICE. (Updated Jan 2006.)

21 Caughey AB, Stotland NE, Washington AE, Escobar Gl. Maternal ethnicity, paternal ethnicity, and parental ethnic discordance: predictors of preeclampsia. Obstet Gynecol 2005;106:156-61.

22 Savvidou M, Hingorani AD, Tsikas D, Frolich IC, Valance P, Nicolaides $\mathrm{KH}$. Endothelial dysfunction and raised plasma concentrations of asymmetric dimethylarginine in pregnant women who subsequently develop pre-eclampsia. Lancet 2003;361:1511-7.

23 Chambers JC, Fusi L, Malik IS, Haskard DO, De Sweit M, Kooner JS. Association of maternal endothelial dysfunction with preeclampsia. IAMA 2001;285:1607-12.
24 Lin J, August P. Genetic thrombophilias and preeclampsia. A metaanalysis. Obstet Gynecol 2005;105:182-92.

25 Paidas MJ, Ku DH, Arkel YS. Screening and management of inherited thrombophilias in the setting of adverse pregnancy outcome. Clin Perinatol 2004;31:783-805.

26 Herrmann J, Lerman LO, Mukhopadhgay D, Napoli C, Lerman A. Angiogenesis in atherosclerosis. Arterioscler Thromb Vasc Biol 2006;26:1948-57.

27 Castles A, Adams K, Melvin CL, Kelsch C, Boulton ML. Effects of smoking during pregnancy. Am J Prev Med 1999;16:208-15.

28 Hammoud AO, Bujold E, Sorokin Y, Schild C, Krapp M, Baumann P. Smoking in pregnancy revisited: findings from a large populationbased study. Am J Obstet Gynecol 2005;192:1856-62.

29 Peters JL, Sutton AJ, Jones DR, Abrams KR, Rushton L. Comparison of two methods to detect publication bias in meta-analysis. JAMA 2006;8;295:676-80

Accepted: 18 July 2007 